\title{
Atherosclerotic Renal Artery Stenosis: Association with Emerging Vascular Risk Factors
}

\author{
Kosmas I. Paraskevas ${ }^{a}$ George Hamilton ${ }^{c}$ Jenny M. Cross ${ }^{b}$ \\ Dimitri P. Mikhailidis ${ }^{d}$ \\ ${ }^{a}$ Department of Clinical Biochemistry and Academic Department of Surgery, and ${ }^{b}$ Renal Unit, Royal Free Hospital, \\ and ${ }^{C}$ Vascular Surgery, Academic Department of Surgery, and ${ }^{d}$ Department of Clinical Biochemistry, Royal Free \\ Hospital and Royal Free University College Medical School, London, UK
}

\author{
Key Words \\ Atherosclerotic renal artery stenosis - Renal function • \\ Homocysteine • Fibrinogen - C-reactive protein • \\ Lipoprotein $(\mathrm{a}) \cdot$ Creatinine
}

\begin{abstract}
Background: The established risk factors for atherosclerotic renal artery stenosis (ARAS) include hypertension, diabetes mellitus, dyslipidemia, obesity, smoking, old age and family history. In the last few years, several emerging risk factors have been proposed as predictors of ARAS, namely homocysteine, fibrinogen, C-reactive protein, lipoprotein(a) and creatinine. Methods: We searched Pubmed/Medline for studies investigating the prognostic value of each of these emerging risk factors in ARAS. Results: Creatinine and C-reactive protein seem to be the most promising predictors of ARAS, whereas the prognostic value of homocysteine, lipoprotein(a) and fibrinogen is not yet fully determined. Conclusion: The establishment of a definite role for these emerging risk factors could result in earlier recognition and/ or better management of ARAS with potential regression/ slowing down of progression of stenosis. Modifying these markers may also improve the therapeutic approach of the
\end{abstract}

\section{KARGER}

Fax +41613061234

E-Mail karger@karger.ch

www.karger.com (c) 2007 S. Karger AG, Basel

$1660-2110 / 08 / 1081-0056 \$ 24.50 / 0$

Accessible online at:

www.karger.com/nec associated systemic atherosclerosis in these high-risk patients. Future trials should focus on the effect of different classes of drugs (e.g. statins and fibrates) on the levels of the emerging risk factors and the association with ARAS progression.

Copyright $\odot 2007$ S. Karger AG, Basel

\section{Introduction}

The population-based prevalence of atherosclerotic renovascular disease (ARVD), defined as $\geq 60 \%$ atherosclerotic renal artery stenosis (ARAS) or occlusion, is approximately $7 \%$ in adults $>65$ years [1]. ARAS is 1 aspect of a multiterritory (systemic) atherosclerotic disease. This concept is supported by the observations that ARAS is identified in approximately $12 \%$ of the subjects undergoing coronary angiography $[2,3]$ and $26 \%$ of the subjects investigated for peripheral arterial disease (PAD) [4].

Renal ischemia resulting from ARAS has 2 important sequelae: (1) systemic hypertension (frequently requiring multiple antihypertensive agents) placing the individual at increased risk of stroke and myocardial infarction (MI) $[5,6]$, and (2) renal atrophy and nephron loss (strong cor-

Dimitri P. Mikhailidis, MD, FFPM, FRCPath, FRCP

Department of Clinical Biochemistry

Royal Free Hospital and Royal Free University College Medical School

Pond Street, London NW3 2QG (UK)

Tel. +44 207830 2258, Fax +44 207830 2235, E-Mail mikhailidis@aol.com 
relation between the degree of ARAS and the risk of renal atrophy, $\mathrm{p}=0.009)$ [7]. ARAS is therefore a cause of both hypertension and renal insufficiency $[8,9]$. The latter is coupled with an increased risk of progression to endstage renal disease $[5,6]$. As a result, ARAS is the underlying disease in $10-40 \%$ of the patients entering dialysis programs $[10,11]$.

A variety of techniques exist with which to anatomically evaluate ARAS. Intra-arterial digital subtraction angiography is the standard diagnostic test for ARAS [12]. However, it is not without risk; these procedures are associated in up to $50 \%$ of the cases with a temporary or permanent reduction in glomerular filtration rate that may relate either to contrast nephropathy (both iodinebased and more recently gadolinium-associated) [12] or to cholesterol embolization [13]. Renal artery duplex scanning can be performed with high levels of accuracy and reproducibility in patients with ARAS [14-18]. Additional advantages include being noninvasive and less expensive than intra-arterial digital subtraction angiography. However, it is often impossible to obtain good imaging in obese patients [13]. Other tests also exist (e.g. spiral computed tomography, isotope renography and magnetic resonance angiography) but each has advantages and disadvantages [13].

Identification of risk factors that predispose to ARAS is crucial for the development of strategies for prevention. Hypertension [19-23], diabetes mellitus [19, 20, 22, 24], dyslipidemia [21, 23, 25, 26], obesity [27-30], smoking [21, $31]$, older age $[1,21,32,33]$ and family history [34-36] comprise established risk factors for ARAS and ARVD. Emerging risk factors include deteriorating renal function (as defined by rising serum creatinine levels), homocysteine, fibrinogen, C-reactive protein (CRP) and lipo$\operatorname{protein}(\mathrm{a})[\mathrm{Lp}(\mathrm{a})]$.

This review considers the role of emerging risk factors in ARAS.

\section{Literature Search Method}

We searched Medline for studies evaluating the role of emerging risk factors for ARAS. The search terms used were 'atherosclerosis', 'renal artery stenosis', 'risk factors', 'fibrinogen', 'C-reactive protein', 'lipoprotein(a)', 'homocysteine' and 'creatinine' in various combinations. The reference lists of the selected reports were manually searched for additional studies. These were also considered in our review.

Atherosclerotic Renal Artery Stenosis

\section{Literature Search Results}

Several plasma constituents have been identified as potential risk factors for the development of ARAS. For some, current evidence is not adequate; others have an established role in predicting ARAS.

We discuss the literature data regarding the prognostic role of each of the proposed emerging risk factors.

\section{Fibrinogen}

Fibrinogen is an acute phase protein, whose production may be enhanced by the inflammatory process associated with atherosclerosis [37]. Fibrinogen is a major determinant of plasma viscosity and it can influence red cell aggregation, platelet activation and coagulation [37]. Furthermore, atherosclerotic plaques have been shown to contain fibrinogen, fibrin and fibrinogen degradation products, which may play a role in smooth muscle cell proliferation and act as chemoattractants for leukocytes [37]. These proatherogenic properties may play a role in the pathogenesis of ARAS.

Plasma fibrinogen levels correlate with the risk of PAD [37-41], coronary heart disease (CHD) [37, 38, 42], MI $[38,42]$, the extent of aortic atherosclerosis [38, 43], carotid intima media thickness $[38,44]$, a worse outcome in patients with ischemic stroke [45] as well as an increased risk of recurrent ischemic stroke [46].

The role of fibrinogen in ARAS was investigated in 270 patients (193 men, 77 women; mean age: 59 years) with CHD [47]. By univariate logistic regression analysis, older age ( $68 \pm 8$ vs. $58 \pm 10$ years, for ARAS vs. no ARAS, respectively), the presence of hypertension (61 vs. $38 \%)$, a high plasma fibrinogen level (391 \pm 93 vs. $335 \pm$ $109 \mathrm{mg} / \mathrm{dl})$, a low albumin level $(39 \pm 4$ vs. $41 \pm 4 \mathrm{~g} / \mathrm{l})$ and a low hemoglobin level $(12.5 \pm 1.6$ vs. $13.5 \pm 1.6 \mathrm{~g} /$ dl) were associated with the presence of ARAS (for all associations, $\mathrm{p}<0.05)$. On the other hand, serum lipids, Lp(a), creatinine, sex, smoking and diabetes were not associated with ARAS. By multivariate logistic regression analysis, older age [odds ratio $(\mathrm{OR})=2.4, \mathrm{p}=0.0001$ ], the presence of hypertension $(\mathrm{OR}=2.68, \mathrm{p}=0.039)$ and a higher fibrinogen level $(\mathrm{OR}=1.63, \mathrm{p}=0.038)$ were significant risk factors of ARAS [47]. These results suggest that hyperfibrinogenemia, as well as old age and hypertension, are independent risk factors for ARAS.

A recent trial verified the association between elevated fibrinogen levels and the presence of ARAS [2]. After performing renal angiography in 333 hypertensive patients with CHD, significant $(>50 \%)$ and nonsignificant $(<50 \%)$ ARAS was identified in $12 \%$ (40 patients) and $13.5 \%$ (45

Nephron Clin Pract 2008;108:c56-c66 
patients) of the group, respectively. Patients with $>50 \%$ ARAS had higher fibrinogen levels compared with nonARAS patients $(402.5 \pm 122.7$ vs. $354.0 \pm 104.8 \mathrm{mg} / \mathrm{dl}$, respectively; $p<0.01$ ] [2]. In univariate analysis, plasma fibrinogen levels were significantly associated with ARAS [estimated OR $=1.036,95 \%$ confidence interval $(\mathrm{CI})=$ $1.008-1.065, \mathrm{p}=0.01]$ [2].

The strong association between elevated plasma fibrinogen levels and the presence of ARAS was demonstrated in another study [48]. The plasma fibrinogen levels were approximately $25 \%$ higher in ARAS patients compared with controls (325.9 \pm 70.0 vs. $256.2 \pm 54.7$ $\mathrm{mg} / \mathrm{dl}$, for ARAS and control patients, respectively, $\mathrm{p}<$ $0.05)$ [48]. However, the small number of patients involved (15 patients with ARAS and 27 controls) is an important limitation [48]. In an earlier study, the same group reported that preinterventional plasma fibrinogen levels correlate with restenosis 1-6 months following percutaneous transluminal renal angioplasty (PTRA) performed for ARAS ( $\mathrm{p}<0.01$ ) [49].

The evidence for the predictive value of fibrinogen in ARAS is therefore still limited. Its role as a prognostic marker for ARAS should be verified in larger scale trials before definite conclusions are drawn.

\section{C-Reactive Protein}

High circulating CRP levels are related with future cardiovascular event rates in both stable and unstable angina [50]. CRP is also associated with increased risk of carotid atherosclerosis [51, 52], CHD [53-55], MI [56, 57], stroke [58-60] and PAD [61-63]. In the Rotterdam Study, CRP levels predicted progression of atherosclerosis measured noninvasively at various sites of the arterial tree (carotid, aortic, iliac and lower extremity) [64]. It has been suggested that measuring CRP, in addition to traditional risk factors, may improve the ability to predict cardiovascular events [65]. Besides being a predictor of vascular risk, CRP may be directly involved in atherogenesis $[66,67]$. Such actions may include proinflammatory cytokine release, promotion of monocyte chemotaxis and adhesion, vascular smooth muscle cell proliferation and oxidized low-density lipoprotein (LDL) uptake $[66,67]$. However, this role for CRP in atherogenesis remains speculative, as is its role in the pathogenesis of ARAS.

CRP levels were measured in 95 hypertensive patients clinically at risk of ARAS, who then underwent intra-arterial digital subtraction angiography [68]. The median serum CRP concentrations were significantly higher among the 57 patients with atherosclerosis of the aorta and/or renal arteries compared with those in the
26 patients without any angiographic lesions (4.6 vs. 1.7 $\mathrm{mg} / \mathrm{l} ; \mathrm{p}<0.005)$. Moreover, in patients with ARAS, the CRP levels were higher when the degree of stenosis exceeded $50 \%$. It was concluded that CRP concentrations correlate with atherosclerotic lesions in the renal arteries and the abdominal aorta, thus supporting the view that ARAS is part of a systemic inflammatory vascular disease [68]. In addition, CRP levels correlate with renal function [69].

CRP levels constitute a late marker of systemic inflammatory response to renal artery stenting [70,71]. A recent study also demonstrated that ARAS patients with restenosis had higher CRP levels compared with similar patients without restenosis $[7.694 \pm 0.39$ vs. $1.56 \pm 1.08$ $\mathrm{mg} / \mathrm{l}$, for patients with $(\mathrm{n}=10)$ vs. without $(\mathrm{n}=20)$ restenosis, respectively; $\mathrm{p}=0.001$ ] [72]. The conclusion reached was that CRP levels might be an independent predictor of recurrent stenosis in ARAS. An independent group verified this association [2]; patients with ARAS had higher high-sensitivity CRP levels compared with controls $(7.87 \pm 4.81$ vs. $5.57 \pm 3.86 \mathrm{~g} / \mathrm{l}$, respectively; $\mathrm{p}<$ 0.05). By univariate analysis, high-sensitivity CRP levels were associated with the presence of ARAS (estimated $\mathrm{OR}=1.137,95 \% \mathrm{CI}=1.040-1.243 ; \mathrm{p}=0.005)$ [2].

These results suggest that CRP is a marker of ARAS and renal function.

\section{Lipoprotein(a)}

Lp(a) shares a structural homology with plasminogen and therefore may impair fibrinolysis [73]. There is also some evidence showing that $\mathrm{Lp}(\mathrm{a})$ can enhance platelet activation [74]. Lp(a) may also be involved in restenosis following infrainguinal bypass [75]. Other atherogenic actions of $\operatorname{Lp}(\mathrm{a})$ have been described and are reviewed elsewhere [73]. The role of $L p(a)$ in the pathogenesis of ARAS may be confounded by the potential rise in circulating levels of this lipoprotein in the presence of impaired renal function [73].

Serum Lp(a) levels correlate significantly with the risk of MI [76], PAD [77], CHD [78] and stroke [79, 80] as well as the risk of developing intermittent claudication [76]. Its role in ARAS has not been extensively investigated.

Scoble et al. [81] examined the lipoprotein profiles in patients with proven ARAS and compared them with patients matched for age, gender, renal function and the presence of diabetes. Although no significant difference was demonstrated for apolipoprotein B, cholesterol, LDL cholesterol, fibrinogen, high-density lipoprotein cholesterol and triglyceride levels between the groups, the serum $L p(a)$ levels were higher in the control group (com- 
pared with the ARAS group; $58 \pm 45$ vs. $31 \pm 21 \mathrm{mg} / \mathrm{dl}$, respectively; $\mathrm{p}<0.01$ ).

A strong positive association was reported in a young man with aggressive arterial occlusive disease in the lower extremities and symptom-free occlusions of coronary and renal arteries in association with high levels of $L p(a)$ [82]. On the other hand, a study attempting to identify the risk factors for renal artery stenosis in 427 patients (mean age: $59.2 \pm 10.3$ years) failed to demonstrate a significant correlation between serum Lp(a) levels with ARAS by univariate logistic regression analysis $(29.4 \pm$ 30.3 vs. $25.3 \pm 23.1 \mathrm{mg} / \mathrm{dl}$, for patients with and without ARAS, respectively, $\mathrm{p}=0.41$ ) [83].

Therefore, there is no consistent evidence at this stage that $\operatorname{Lp}(\mathrm{a})$ is an important independent risk factor for ARAS.

\section{Homocysteine}

The hypothesis that homocysteine plays an active role in vascular disease was first proposed almost half a century ago [84]. The basis of this hypothesis was the observation that the pathological findings in an infant with a rare inborn error of $B_{12}$ metabolism were similar to those in infants with cystathione B-synthase deficiency. This observation led to the conclusion that elevation of blood homocysteine values (the only metabolic abnormality shared in these disorders) was the cause of the vascular disease in these children.

Since then, numerous studies investigated the role of homocysteine as a predictor of vascular diseases. A positive association was demonstrated between plasma homocysteine levels and extent of atherosclerosis $[85,86]$, as well as the risk of hypertension [87], stroke [85-88], carotid artery disease $[89,90], \mathrm{CHD}[87,91,92], \mathrm{PAD}[93$, $94]$ as well as MI $[95,96]$.

Homocysteine may exhibit several atherogenic [97] and prothrombotic [98] actions. However, intervention trials have not demonstrated any convincing benefit when the circulating homocysteine levels were lowered [97]. As with Lp(a), the role of homocysteine in the pathogenesis of ARAS may be confounded by the potential rise in circulating levels in the presence of impaired renal function [97].

The plasma homocysteine concentrations were significantly higher in patients with ARAS compared with controls $(11.0 \pm 3.9$ vs. $6.8 \pm 1.3 \mu \mathrm{mol} / \mathrm{l}$, respectively; $\mathrm{p}<$ 0.05) [48]. However, the results of this study are underpowered due to the small number of subjects included (15 patients with ARAS and 27 healthy controls).

Atherosclerotic Renal Artery Stenosis
A larger study [99] showed that the plasma homocysteine levels were significantly higher in ARAS $(n=25)$ patients (median: $15.3 \mu \mathrm{mol} / \mathrm{l}$, range: $8.4-40.1$ ) when compared with healthy $(\mathrm{n}=25)$ controls (median: 9.9 $\mu \mathrm{mol} / \mathrm{l}$, range: $7.1-20.7, \mathrm{p}<0.001$ ). Nevertheless, following PTRA, the homocysteine levels were only marginally decreased compared with baseline in the 18 of the $25 \mathrm{pa}$ tients that were eligible at the 6-month follow-up (median: $14.9 \mu \mathrm{mol} / \mathrm{l}$, range: $9.4-33.8$, vs. median: $14.6 \mu \mathrm{mol} / \mathrm{l}$, range: 7.9-45.8, for baseline and 6 months after revascularization). This finding questions the validity of plasma homocysteine levels as an independent marker of ARAS.

In another trial, homocysteine levels were recorded in 58 patients with angiographically documented ARAS and mildly impaired renal function [100]. A total of 102 normotensive subjects were considered as the control group. The mean total homocysteine levels were significantly higher in patients than in controls $(\mathrm{p}<0.01)$, as was the prevalence of hyperhomocysteinemia (51.7 vs. $32.3 \%$, for patients vs. controls, respectively, $\mathrm{p}<0.05$ ). The authors concluded that hyperhomocysteinemia is common in patients with ARAS. The outcome of a recent study strengthens this association [2]; in this study, the plasma homocysteine values significantly correlated with ARAS $(14.6 \pm 7.0$ vs. $11.5 \pm 4.2 \mu \mathrm{mol} / \mathrm{l}$, for patients with vs. without ARAS, respectively; $\mathrm{p}<0.05$ ). Additionally, when homocysteine was tested using univariate logistic regression analysis for association with ARAS, a positive association was reported (estimated OR $=1.106,95 \%$ $\mathrm{CI}=1.107-1,342 ; \mathrm{p}=0.001)[2]$.

Thus, the majority of studies seem to support an association between plasma homocysteine levels and ARAS $[2,48,100]$. However, opposing results were reported in another study [99]. Hypertensive ARAS patients $(\mathrm{n}=25)$ had higher baseline homocysteine levels compared with healthy $(\mathrm{n}=25)$ subjects [15.3 (range: $8.4-40.1)$ vs. 9.9 (range: 7.1-20.7) $\mu \mathrm{mol} / \mathrm{l}$, for ARAS patients and healthy subjects, respectively; $\mathrm{p}<0.001]$. Of the ARAS group, 18 patients underwent renal revascularization. In this subgroup, the homocysteine levels were not reduced significantly 6 months following renal revascularization compared with baseline values [14.9 (range: 9.4-33.8) vs. 14.6 (range: 7.9-45.8) $\mu \mathrm{mol} / \mathrm{l}$, respectively; $\mathrm{p}=$ not significant]. Thus, the role of homocysteine in ARAS needs to be elucidated.

\section{Creatinine}

It is now widely accepted that impaired renal function (as determined by plasma creatinine levels) is associated

Nephron Clin Pract 2008;108:c56-c66 
with a greater risk of vascular events [101-104]. Thus, renal and ischemic heart disease may progress in parallel [101-104]. This association may reflect an adverse vascular risk profile in patients with even marginally impaired renal function $[103,104]$.

Elevated creatinine values (a surrogate for reduced glomerular filtration rate) predict a worse outcome (higher morbidity and mortality rates) following MI [105-109]. An elevated creatinine is also associated with an increased risk of ischemic stroke and transient ischemic attack episodes [110, 111], incidence of CHD [112] and allcause cardiovascular mortality [109, 111, 112]. Furthermore, plasma creatinine values correlate with deteriorating renal function in untreated dyslipidemic patients with CHD [101, 102].

The role of creatinine in predicting significant $(\geq 50 \%$ luminal diameter narrowing) ARAS was investigated in a study including 427 patients undergoing cardiac catheterization. By univariate logistic regression analysis, plasma creatinine values $\geq 1.5 \mathrm{mg} / \mathrm{dl}(115 \mu \mathrm{mol} / \mathrm{l})$ were strong predictors of significant ARAS $(p=0.0001)$ [83]. Overall, $10.5 \%$ of the patients undergoing cardiac catheterization had concurrent ARAS. In half of them, the stenosis was significant ( $\geq 50 \%$ luminal diameter narrowing). The authors proposed the performance of routine abdominal aortography at the time of cardiac catheterization to evaluate the renal vasculature in this potentially high-risk group [83]. These results were verified in a recent study with similar design [113]. Of 1,200 consecutive patients undergoing coronary angiography, significant $(\geq 50 \%)$ ARAS was present in almost 1 for every 10 patients (116 patients or $9.7 \%$ ). By multivariate logistic regression analysis, serum creatinine levels $\geq 133$ $\mu \mathrm{mol} / \mathrm{l}$ were a predictor of significant ARAS. The results of these 2 studies $[83,113]$ suggest that creatinine levels should not only be used as a diagnostic test for the verification of renal impairment and ARVD but also as an important predictor for the presence of ARAS. Additionally, the association between ARAS and CHD suggests that atherosclerosis is a multisystemic disease simultaneously affecting different vascular beds. The hypothesis of a systemic, multiterritory atherosclerotic disease, which would imply a possible association between ARAS and $\mathrm{CHD}$, has also been proposed in other independent studies [2, 114-118].

Another study investigated the risk factors affecting long-term ( $>5$ years) outcome, survival and renal function in 195 patients with ARVD treated invasively or medically [119]. Of the patient group, 54 were randomly assigned to medical treatment (antihypertensive and lip- id-lowering drugs) and 136 underwent PTRA. Five patients were lost to follow-up. The average follow-up was $54.4 \pm 40.4$ months (range: 12-189). A multivariate logistic regression analysis [using age, sex, smoking habit, diabetes, presence of vascular comorbidity, total and LDL cholesterol, baseline creatinine, hypertension, type (monolateral or bilateral) and degree $(>75$ or $<75 \%$ ) of stenosis, type of treatment (medical or invasive) and use of statins or angiotensin-converting enzyme inhibitors as variables] showed that, besides the use of angiotensinconverting enzyme inhibitors, the only significant predictor of renal function impairment was an abnormal baseline serum creatinine $(\geq 1.6 \mathrm{mg} / \mathrm{dl} ; 123 \mu \mathrm{mol} / \mathrm{l}$; hazard ratio $=1.42,95 \% \mathrm{CI}=1.03-1.95, \mathrm{p}=0.028)$. When the same variables were used to calculate the risk for endstage renal disease, the multivariate analysis produced baseline serum creatinine as the only predictor (hazard ratio $=1.66,95 \% \mathrm{CI}=1.22-2.264, \mathrm{p}=0.001)$. The prognostic role of creatinine was additionally supported by the fact that in the patients who did not proceed to endstage renal disease, the change in serum creatinine during the study period was very modest [119]. The prognostic role of serum creatinine in progressive ARVD and worsening renal function was also demonstrated in other studies [120-122].

An interesting hypothesis was expressed in a trial investigating individual kidney function in ARAS [123]. In patients with unilateral ARAS, split kidney glomerular filtration rate was demonstrated to be similar in the stenosed compared with the nonstenosed kidney (17.32 vs. $13.6 \mathrm{ml} / \mathrm{min}$, respectively; $\mathrm{p}=0.22$ ) [123]. However, a reduction in split kidney glomerular filtration rate with increasing degree of stenosis was noted $(<30 \%, 27 \mathrm{ml} / \mathrm{min}$; $30-60 \%, 17.7 \mathrm{ml} / \mathrm{min} ;>60 \%$ stenosis, $15 \mathrm{ml} / \mathrm{min} ; \mathrm{p}=$ 0.016 ). It was thus hypothesized that in patients with ARAS the individual kidney function would be equal between the 2 kidneys until the degree of stenosis was sufficient to cause a decrement in renal function [123]. The findings from this study support the role of creatinine as a predictor of ARAS and deteriorating renal function.

Another study [99] showed that creatinine clearance was significantly lower in ARAS $(n=25)$ patients (median: $60 \mathrm{ml} / \mathrm{min}$, range: $19-133$ ) when compared not only with healthy $(\mathrm{n}=25)$ controls (median: $93 \mathrm{ml} / \mathrm{min}$, range: $62-141, \mathrm{p}<0.001)$ but also with patients $(\mathrm{n}=25)$ with documented essential hypertension (median: $102 \mathrm{ml} /$ min, range: $50-147, p<0.001$ ). Furthermore, following PTRA, creatinine clearance improved significantly compared with baseline in the 18 of the 25 patients that were eligible at the 6-month follow-up (median: $52 \mathrm{ml} / \mathrm{min}$, 
range: $26-164$, vs. median: $63 \mathrm{ml} / \mathrm{min}$, range: $18-151$, for baseline and 6 months after revascularization, $\mathrm{p}<0.05$ ). Other studies have similarly demonstrated that serum creatinine values can be used to predict improvement in renal function following PTRA $[124,125]$. Furthermore, ARAS patients undergoing PTRA with creatinine values $>300 \mu \mathrm{mol} / \mathrm{l}(3.9 \mathrm{mg} / \mathrm{dl})$ have almost 5-fold higher mortality rates compared with patients with creatinine values $<300 \mu \mathrm{mol} / \mathrm{l}$ (relative risk $=4.7,95 \% \mathrm{CI}=2.0-11.0, \mathrm{p}<$ $0.0005)$ [126].

The encouraging evidence from PTRA studies involved small numbers of patients and had several design limitations. Large-scale randomized trials will determine whether or not revascularization is indeed superior to medical treatment $[127,128]$. The results of these trials are expected to provide more reliable evidence regarding the optimal treatment options.

ARAS and chronic kidney disease are common partners, but this may be because they share common etiologies (i.e. atherosclerosis) and not directly due to renal artery stenosis. Therefore, it is difficult to attribute a rise in plasma creatinine levels to an exact pathogenetic mechanism. Nevertheless, creatinine is a promising emerging vascular risk factor that can be used to successfully predict not only progressive ARAS but also improvement of renal function following PTRA.

\section{Potential for Modifying Emerging Risk Factors}

\section{Fibrinogen}

The effect of drugs on plasma fibrinogen levels has been reviewed elsewhere [37]. Briefly, fibrates can lower fibrinogen levels. However, these drugs are also associated with an elevation of plasma creatinine levels. Therefore, their use may be limited in patients with ARAS. The effect of statins on plasma fibrinogen levels is not consistent. Different antihypertensive agents may also have a variable effect on fibrinogen levels [37, 129]. One problem with assessing the role of fibrinogen in ARAS, or for that matter in any atherosclerotic disease, is that there is no drug that will selectively alter the circulating levels of this coagulation factor. All the drugs mentioned above simultaneously influence other risk factors [37].

\section{C-Reactive Protein}

Serum CRP levels are reduced by both fibrates and statins [130, 131]. There is a link between the extent of reduction in CRP levels by statins and outcome in clinically relevant events in patients with CHD $[132,133]$. Sev- eral drugs, other than statins and fibrates, can lower plasma CRP levels in patients with vascular disease [134]. Whether a similar association exists between reduction of CRP levels and ARAS progression needs to be determined. In any case, the value of lowering plasma CRP levels in terms of reducing the risk of vascular events remains unconfirmed.

\section{Lipoprotein(a)}

Hormone replacement therapy can lower the serum $\mathrm{Lp}(\mathrm{a})$ levels in postmenopausal women [135]. Beyond that option, Lp(a) levels cannot be easily reduced [136]. However, there is some evidence that the harmful effect of Lp(a) can be 'neutralized', at least in part, by aggressive LDL cholesterol lowering treatment [136]. To our knowledge, there is no clearly defined evidence showing that lowering the $\mathrm{Lp}(\mathrm{a})$ levels results in reduction of vascular events or risk of ARAS progression.

\section{Homocysteine}

Plasma homocysteine levels can be lowered by vitamin supplementation $\left(B_{12}, B_{6}\right.$ and/or folic acid) [137]. However, the results of intervention trials are not encouraging in terms of reductions of vascular events [137].

\section{Creatinine}

Statins may exert a nephroprotective effect in patients with CHD resulting in an improved estimated glomerular filtration rate or a decreased deterioration in estimated glomerular filtration rate over time [101, 138]. Other drugs have also been reported to 'preserve' renal function [139]. However, it is likely that creatinine is only a marker of risk rather than directly involved in the pathogenesis of ARAS. Thus, lowering plasma creatinine levels may reflect beneficial actions in other processes (e.g. endothelial function or renal blood flow) [103]. It follows that the role of these agents in ARAS needs to be investigated.

\section{Conclusions}

ARAS is probably underdiagnosed despite a substantial prevalence in patients with vascular disease $[1-3,127$, 140]. ARAS is commonly found by chance during angiography for other reasons [141].

The value of emerging risk factors in predicting ARAS is not yet fully determined. Creatinine and CRP seem to be the most promising predictors, whereas the evidence regarding homocysteine, $\mathrm{Lp}(\mathrm{a})$ and fibrinogen is still in- 
adequate. Establishment of a definite role for these risk factors could result in better treatment with potential regression or arrest/slowing down of progression of stenosis in patients with ARAS. As a result of such a beneficial effect, prognosis may improve, and so will other vascular risk factors (such as blood pressure and possibly dyslipidemia associated with impaired renal function).

Furthermore, ARAS is often accompanied by vascular disease in at least 1 additional arterial bed, namely PAD [142-146], abdominal aortic disease [146-149], carotid artery disease [145, 150-152] and/or CHD $[2,114,116$, $152,153]$. This was recently verified in a cohort of patients with CHD. The frequency of ARAS increased in proportion with the number of stenotic coronary arteries [2]; the incidence of ARAS was $10,15.8$ and $18.1 \%$ in patients with single-vessel, 2-vessel and 3-vessel CHD, respectively [2]. It derives that treatment of vascular risk factors would result in better management of the widespread atherosclerotic disease in this high-risk population.

\section{References}

$\checkmark 1$ Hansen KJ, Edwards MS, Craven TE, Cherr GS, Jackson SA, Appel RG, Burke GL, Dean $\mathrm{RH}$ : Prevalence of renovascular disease in the elderly: a population-based study. J Vasc Surg 2002;36:443-451.

$\checkmark 2$ Dzielinska Z, Januszewicz A, Demkow M, Makowiecka-Ciesla M, Prejbisz A, Naruszewicz M, Nowicka G, Kadziela J, Zielinski T, Florczak E, Janas J, Januszewicz M, Ruzyllo $\mathrm{W}$ : Cardiovascular risk factors in hypertensive patients with coronary artery disease and coexisting renal artery stenosis. $\mathrm{J} \mathrm{Hy}$ pertens 2007;25:663-670.

-3 Cohen MG, Pascua JA, Garcia-Ben M, RojasMatas CA, Gabay JM, Berrocal DH, Tan WA, Stouffer GA, Montoya M, Fernandez AD, Halac ME, Grinfeld LR: A simple prediction rule for significant renal artery stenosis in patients undergoing cardiac catheterization. Am Heart J 2005;150:1204-1211.

-4 Mui KW, Sleeswijk M, van den Hout H, van Baal J, Navis G, Woittiez AJ: Incidental renal artery stenosis is an independent predictor of mortality in patients with peripheral vascular disease. J Am Soc Nephrol 2006;17: 2069-2074.

5 Safian RD, Textor SC: Renal-artery stenosis. N Engl J Med 2001;344:431-442.

6 Rimmer JM, Gennari FJ: Atherosclerotic renovascular disease and progressive renal failure. Ann Intern Med 1993;119:712-719.

7 Caps MT, Zierler RE, Polissar NL, Bergelin RO, Beach K, Cantwell-Gab K, Casadei A, Davidson RC, Strandness DE Jr: Risk of atrophy in kidneys with atherosclerotic renal artery stenosis. Kidney Int 1998;53:735742.

$\checkmark 8$ Jacobson HR: Ischemic renal disease: an overlooked clinical entity? Kidney Int 1988; 34:729-743.

-9 Working Group on Renovascular Hypertension: Detection, evaluation, and treatment of renovascular hypertension: final report. Arch Intern Med 1987;147:820-829.
10 Preston RA, Epstein M: Ischemic renal disease: an emerging cause of chronic renal failure and end-stage renal disease. J Hypertens 1997;15:1365-1377.

11 Van Ampting JM, Penne EL, Beek FJ, Koomans HA, Boer WH, Beutler JJ: Prevalence of atherosclerotic renal artery stenosis in patients starting dialysis. Nephrol Dial Transplant 2003;18:1147-1151.

12 Erley CM, Bader BD, Berger ED, Tuncel N, Winkler S, Tepe G, Risler T, Duda S: Gadolinium-based contrast media compared with iodinated media for digital subtraction angiography in azotaemic patients. Nephrol Dial Transplant 2004;19:2526-2531.

13 McLaughlin K, Jardine AG, Moss JG: ABC of arterial and venous disease: renal artery stenosis. BMJ 2000;320:1124-1127.

14 Hoffmann U, Edwards JM, Carter S, Goldman ML, Harley JD, Zaccardi MJ, Strandness DE Jr: Role of duplex scanning for the detection of atherosclerotic renal artery disease. Kidney Int 1991;39:1232-1239.

15 Kohler TR, Zierler RE, Martin RL, Nicholls SC, Bergelin RO, Kazmers A, Beach KW, Strandness DE Jr: Noninvasive diagnosis of renal artery stenosis by ultrasonic duplex scanning. J Vasc Surg 1986;4:450-456.

16 Taylor DC, Kettler MD, Moneta GL, Kohler TR, Kazmers A, Beach KW, Strandness DE Jr: Duplex ultrasound scanning in the diagnosis of renal artery stenosis: a prospective evaluation. J Vasc Surg 1988;7:363-369.

17 Olin JW, Piedmonte MR, Young JR, DeAnna S, Grubb M, Childs MB: The utility of duplex ultrasound scanning of the renal arteries for diagnosing significant renal artery stenosis. Ann Intern Med 1995;122:833-838.

18 Hansen KJ, Tribble RW, Reavis SW, Canzanello VJ, Craven TE, Plonk GW Jr, Dean RH: Renal duplex sonography: evaluation of clinical utility. J Vasc Surg 1990;12:227236.

19 Lea JP, Nicholas SB: Diabetes mellitus and hypertension: key risk factors for kidney disease. J Natl Med Assoc 2002;94:7S-15S.
20 Ferguson R, Morrissey E: Risk factors for end-stage renal disease among minorities. Transplant Proc 1993;25:2415-2420.

21 Wang Y, Ho DS, Chen WH, Wang YQ, Lam WF, Shen ZJ, Lu CZ, Chui M: Prevalence and predictors of renal artery stenosis in Chinese patients with coronary artery disease. Intern Med J 2003;33:280-285.

22 Caps MT, Perissinotto C, Zierler RE, Polissar NL, Bergelin RO, Tullis MJ, Cantwell-Gab K, Davidson RC, Strandness DE Jr: Prospective study of atherosclerotic disease progression in the renal artery. Circulation 1998;98: 2866-2872.

-23 Manttari M, Tiula E, Alikoski T, Manninen V: Effects of hypertension and dyslipidemia on the decline in renal function. Hypertension 1995;26:670-675.

24 Pugh JA, Medina RA, Cornell JC, Basu S: NIDDM is the major cause of diabetic endstage renal disease: more evidence from a triethnic community. Diabetes 1995;44:13751380 .

25 Crook ED, Thallapureddy A, Migdal S, Flack JM, Greene EL, Salahudeen A, Tucker JK, Taylor HA Jr: Lipid abnormalities and renal disease: is dyslipidemia a predictor of progression of renal disease? Am J Med Sci 2003; 325:340-348.

26 Keane WF, Kasiske BL, O’Donnell MP: Hyperlipidemia and the progression of renal disease. Am J Clin Nutr 1988;47:157-160.

-27 Henegar JR, Bigler SA, Henegar LK, Tyagi SC, Hall JE: Functional and structural changes in the kidney in the early stages of obesity. J Am Soc Nephrol 2001;12:12111217.

-28 De Jong PE, Verhave JC, Pinto-Sietsma SJ, Hillege HL; PREVEND study group: Obesity and target organ damage: the kidney. Int J Obes Relat Metab Disord 2002;26:S21-S24.

29 Stengel B, Tarver-Carr ME, Powe NR, Eberhardt MS, Brancati FL: Lifestyle factors, obesity and the risk of chronic kidney disease. Epidemiology 2003;14:479-487. 
-30 Brown WW, Peters RM, Ohmit SE, Keane WF, Collins A, Chen SC, King K, Klag MJ, Molony DA, Flack JM: Early detection of kidney disease in community settings: the Kidney Early Evaluation Program (KEEP). Am J Kidney Dis 2003;42:22-35.

-31 Orth SR, Ritz E: The renal risks of smoking: an update. Curr Opin Nephrol Hypertens 2002;11:483-488.

32 Obialo CI, Allison-Ottey S: Kidney disease in elderly minorities. J Natl Med Assoc 2002; 94:76S-82S.

-33 Coen G, Manni M, Giannoni MF, Bianchini G, Calabria S, Mantella D, Pigorini F, Taggi F: Ischemic nephropathy in an elderly nephrologic and hypertensive population. Am J Nephrol 1998;18:221-227.

-34 Spray BJ, Atassi NG, Tuttle AB, Freedman BI: Familial risk, age at onset, and cause of endstage renal disease in white Americans. J Am Soc Nephrol 1995;5:1806-1810.

- 35 Freedman BI, Spray BJ, Tuttle AB, Buckalew VM Jr: The familial risk of end-stage renal disease in African Americans. Am J Kidney Dis 1993;21:387-393.

-36 Bergman S, Key BO, Kirk KA, Warnock DG, Rostant SG: Kidney disease in the first-degree relatives of African-Americans with hypertensive end-stage renal disease. Am J Kidney Dis 1996;27:341-346.

-37 Kakafika AI, Liberopoulos EN, Mikhailidis DP: Fibrinogen: a predictor of vascular disease. Curr Pharm Des 2007;13:1647-1659.

- 38 Fibrinogen Studies Collaboration; Danesh J, Lewington S, Thompson SG, et al: Plasma fibrinogen level and the risk of major cardiovascular diseases and nonvascular mortality: an individual participant meta-analysis. JAMA 2005;294:1799-1809.

39 Paraskevas KI, Baker DM, Vrentzos GE, Mikhailidis DP: The role of fibrinogen and fibrinolysis in peripheral arterial disease. Thromb Res, in press.

-40 Makin AJ, Chung NA, Silverman SH, Lip GY: Thrombogenesis and endothelial damage/dysfunction in peripheral artery disease: relationship to ethnicity and disease severity. Thromb Res 2003;111:221-226.

-41 Price JF, Mowbray PI, Lee AJ, Rumley A, Lowe GD, Fowkes FG: Relationship between smoking and cardiovascular risk factors in the development of peripheral arterial disease and coronary artery disease: Edinburgh Artery Study. Eur Heart J 1999;20:344-353.

-42 Scarabin PY, Aillaud MF, Amouyel P, Evans A, Luc G, Ferrieres J, Arveiler D, JuhanVague I: Associations of fibrinogen, factor VII and PAI-1 with baseline findings among 10500 male participants in a prospective study of myocardial infarction: the PRIME Study - Prospective Epidemiological Study of Myocardial Infarction. Thromb Haemost 1998;80:749-756
43 Taniguchi H, Momiyama Y, Fayad ZA, Ohmori R, Ashida K, Kihara T, Hara A, Arakawa K, Kameyama A, Noya K, Nagata M, Nakamura $\mathrm{H}$, Ohsuzu F: In vivo magnetic resonance evaluation of associations between aortic atherosclerosis and both risk factors and coronary artery disease in patients referred for coronary angiography. Am Heart J 2004;148:137-143.

44 Brzosko S, Lebkowska U, Malyszko J, Hryszko T, Krauze-Brzosko K, Mysliwiec M: Intima media thickness of common carotid arteries is associated with traditional risk factors and presence of ischaemic heart disease in hemodialysis patients. Physiol Res 2005;54:497-504.

45 Di Napoli M, Papa F, Bocola V: Prognostic influence of increased C-reactive protein and fibrinogen levels in ischemic stroke. Stroke 2001;32:133-138.

46 Woodward M, Lowe GD, Campbell DJ, Colman S, Rumley A, Chalmers J, Neal BC, Patel A, Jenkins AJ, Kemp BE, MacMahon SW: Associations of inflammatory and hemostatic variables with the risk of recurrent stroke. Stroke 2005;36:2143-2147.

47 Park JS, Park JH, Kang JY, Yang WS, Kim SB, Park SW, Park SJ: Hyperfibrinogenemia is an independent risk factor for atherosclerotic renal artery stenosis. Am J Nephrol 1999;19: 649-654.

48 Berent H, Kuczynska K, Wocial B, Dutkiewicz-Raczkowska M, Symonides B: Nontraditional atherosclerosis risk factors in patients with renal artery stenosis and hypertension. Pol Merkur Lekarski 2003;15: 380-381.

49 Symonides B, Januszewicz A, Rowinski O, Januszewicz M, Chodakowska J, Berent $\mathrm{H}$, Kuczynska K, Szmigielski C, Malek G, Januszewicz W: Plasma fibrinogen as a risk factor for restenosis after percutaneous transluminal renal angiography in patients with atherosclerotic renal artery stenosis. J Cardiovasc Risk 1999;6:269-272.

50 Haverkate F, Thompson SG, Pyke SD, Gallimore JR, Pepys MB; European Concerted Action on Thrombosis and Disabilities Angina Pectoris Study Group: Production of Creactive protein and risk of coronary events in stable and unstable angina. Lancet 1997; 349:462-466.

51 Watanabe K, Sugiyama S, Kugiyama K, Honda O, Fukushima H, Koga H, Horibata Y, Hirai T, Sakamoto T, Yoshimura M, Yamashita Y, Ogawa H: Stabilization of carotid atheroma assessed by quantitative ultrasound analysis in nonhypercholesterolemic patients with coronary artery disease. J Am Coll Cardiol 2005;46:2022-2030.

52 Anand SS, Razak F, Yi Q, Davis B, Jacobs R, Vuksan V, Lonn E, Teo K, McQueen M, Yusuf S: C-reactive protein as a screening test for cardiovascular risk in a multiethnic population. Arterioscler Thromb Vasc Biol 2004; 24:1509-1515.
3 Nissen SE, Tuzcu EM, Schoenhagen P, Crowe T, Sasiela WJ, Tsai J, Orazem J, Magorien RD, O'Shaughnessy C, Ganz P; Reversal of Atherosclerosis with Aggressive Lipid Lowering (REVERSAL) Investigators: Statin therapy, LDL cholesterol, C-reactive protein, and coronary artery disease. N Engl J Med 2005;352: 29-38.

54 Linton MF, Fazio S; National Cholesterol Education Program (NCEP) - the third Adult Treatment Panel (ATP III): A practical approach to risk assessment to prevent coronary artery disease and its complications. Am J Cardiol 2003;92:19i-26i.

55 DeFilippi C, Wasserman S, Rosanio S, Tiblier E, Sperger H, Tocchi M, Christenson R, Uretsky B, Smiley M, Gold J, Muniz H, Badalamenti J, Herzog C, Henrich W: Cardiac troponin $\mathrm{T}$ and $\mathrm{C}$-reactive protein for predicting prognosis, coronary atherosclerosis, and cardiomyopathy in patients undergoing long-term hemodialysis. JAMA 2003;290:353-359.

56 Sano T, Tanaka A, Namba M, Nishibori Y, Nishida Y, Kawarabayashi T, Fukuda D, Shimada K, Yoshikawa J: C-reactive protein and lesion morphology in patients with acute myocardial infarction. Circulation 2003; 108:282-285.

57 Ridker PM, Cushman M, Stampfer MJ, Tracy $\mathrm{RP}$, Hennekens $\mathrm{CH}$ : Inflammation, aspirin, and the risk of cardiovascular disease in apparently healthy men. N Engl J Med 1997; 336:973-979.

58 Kuo HK, Yen CJ, Chang CH, Kuo CK, Chen $\mathrm{JH}$, Sorond F: Relation of C-reactive protein to stroke, cognitive disorders, and depression in the general population: systematic review and meta-analysis. Lancet Neurol 2005 4:371-380.

59 Sanchez-Moreno C, Dashe JF, Scott T, Thaler D, Folstein MF, Martin A: Decreased levels of plasma vitamin $\mathrm{C}$ and increased concentrations of inflammatory and oxidative stress markers after stroke. Stroke 2004;35: 163-168.

60 Rost NS, Wolf PA, Kase CS, Kelly-Hayes M, Silbershatz H, Massaro JM, D’Agostino RB, Franzblau C, Wilson PW: Plasma concentration of C-reactive protein and risk of ischemic stroke and transient ischemic attack: the Framingham Study. Stroke 2001;32: 2575-2579.

61 Musicant SE, Taylor LM Jr, Peters D, Schuff RA, Urankar R, Landry GJ, Moneta GL: Prospective evaluation of the relationship between C-reactive protein, D-dimer and progression of peripheral arterial disease. J Vasc Surg 2006;43:772-780.

62 Erren M, Reinecke H, Junker R, Fobker M, Schulte H, Schurek JO, Kropf J, Kerber S, Breithardt G, Assmann G, Cullen P: Systemic inflammatory parameters in patients with atherosclerosis of the coronary and peripheral arteries. Arterioscler Thromb Vasc Biol 1999;19:2355-2363. 
-63 Ridker PM, Cushman M, Stampfer MJ, Tracy $\mathrm{RP}$, Hennekens $\mathrm{CH}$ : Plasma concentration of $\mathrm{C}$-reactive protein and risk of developing peripheral vascular disease. Circulation 1998; 97:425-428.

64 Van Der Meer IM, De Maat MP, Hak AE, Kiliaan AJ, Del Sol AI, Van Der Kuip DA, Nijhuis RL, Hofman A, Witteman JC: C-reactive protein predicts progression of atherosclerosis measured at various sites in the arterial tree: the Rotterdam Study. Stroke 2002;33:2750-2755.

65 Ridker PM, Glynn RJ, Hennekens CH: C-reactive protein adds to the predictive value of total and HDL cholesterol in determining risk of first myocardial infarction. Circulation 1998;97:2007-2011.

-66 Ferri C, Croce G, Cofini V, De Berandinis G, Grassi D, Casale R, Properzi G, Desideri G: $\mathrm{C}$-reactive protein: interaction with the vascular endothelium and possible role in human atherosclerosis. Curr Pharm Des 2007; 13:1631-1645.

67 Jialal I, Devaraj S, Venugopal SK: C-reactive protein: risk marker or mediator in atherothrombosis? Hypertension 2004;44:6-11.

-68 Hommels MJ, van der Ven AJ, Kroon AA, Kessels AG, van Dieijen-Visser MP, van Engelshoven JA, Bruggeman CA, de Leeuw PW: $\mathrm{C}$-reactive protein, atherosclerosis and kidney function in hypertensive patients. J Hum Hypertens 2005; 19:521-526.

69 Verhave JC, Hillege HL, Burgerhof JG, Gansevoort RT, de Zeeuw D, de Jong PE; PREVEND Study Group: The association between atherosclerotic risk factors and renal function in the general population. Kidney Int 2005;67:1967-1973.

-70 Li JJ, Fang CH, Jiang H, Hunag CX, Tang QZ, Wang XH, Li GS: Increased C-reactive protein level after renal stent implantation in patients with atherosclerotic renal stenosis. Angiology 2004;55:479-484

-71 Li JJ, Fang CH, Jiang H, Huang CX, Hui RT, Chen MZ: Time course of inflammatory response after renal artery stenting in patients with atherosclerotic renal stenosis. Clin Chim Acta 2004;350:115-121.

72 Reis KA, Onal B, Gonen S, Arinsoy T, Erten Y, Ilgit E, Soylemezoglu O, Derici U, Guz G, Bali M, Sindel S: Angiotensinogen and plasminogen activator inhibitor-1 gene polymorphism in relation to renovascular disease. Cardiovasc Intervent Radiol 2006;29: 59-63.

-73 Anuurad E, Boffa MB, Koschinsky ML, Berglund L: Lipoprotein(a): a unique risk factor for cardiovascular disease. Clin Lab Med 2006;26:751-772.

74 Milionis HJ, Mikhailidis DP, Winder AF: Platelets and lipoprotein (a): a brief overview of their role in the pathogenesis of atherothrombosis. Platelets 1999;10:277-284.
Cheshire NJ, Wolfe JH, Barradas MA, Chambler AW, Mikhailidis DP: Smoking and plasma fibrinogen, lipoprotein (a) and serotonin are markers for postoperative infrainguinal graft stenosis. Eur J Vasc Endovasc Surg 1996;11:479-486.

76 Price JF, Lee AJ, Rumley A, Lowe GD, Fowkes FG: Lipoprotein (a) and development of intermittent claudication and major cardiovascular events in men and women: the Edinburgh Artery Study. Atherosclerosis 2001; 157:241-249.

77 Dionyssiou-Asteriou A, Papastamatiou M, Vatalas I, Bastounis E: Serum Lp(a) lipoprotein levels in patients with atherosclerotic occlusive disease of the lower extremities. Eur J Vasc Endovasc Surg 2000;20:57-60.

78 Goel PK, Bharti BB, Pandey CM, Singh U, Tewari S, Kapoor A, Garg N, Sinha N: A tertiary care hospital-based study of conventional risk factors including lipid profile in proven coronary artery disease. Indian Heart J 2003;55:234-240.

79 Rajecki M, Pajunen P, Jousilahti P, Rasi V, Vahtera E, Salomaa V: Hemostatic factors as predictors of stroke and cardiovascular disease: the FINRISK '92 Hemostasis Study. Blood Coagul Fibrinolysis 2005;16:119-124.

80 Milionis HJ, Winder AF, Mikhailidis DP: Lipoprotein (a) and stroke. J Clin Pathol 2000; 53:487-496.

81 Scoble JE, de Takats D, Ostermann ME, Connolly JO, Scott NR, Beeso JA, Poyser KH, Peters TJ, Sherwood RA: Lipid profiles in patients with atherosclerotic renal artery stenosis. Nephron 1999;83:117-121.

82 Levy PJ, Gonzalez F, Sheridan D, Carter J, Haynes JL: Diffuse arterial thrombosis in a young man with elevated lipoprotein(a) and minimal atherosclerosis. Cardiovasc Surg 1995;3:56-59.

83 Song HY, Hwang JH, Noh H, Shin SK, Choi DH, Shim WH, Lee HY, Cho SY, Han DS, Choi KH: The prevalence and associated risk factors of renal artery stenosis in patients undergoing cardiac catheterization. Yonsei Med J 2000;41:219-225.

84 McCully KS: Vascular pathology of homocysteinemia: implications for the pathogenesis of arteriosclerosis. Am J Pathol 1969;56: 111-128.

85 Urbanska EM, Luchowski P, Luchowska E, Pniewski J, Wozniak R, Chodakowska-Zebrowska M, Lazarewicz J: Serum kynurenic acid positively correlates with cardiovascular disease risk factor, homocysteine: a study in stroke patients. Pharmacol Rep 2006;58: 507-511.

86 Hankey GJ: Is plasma homocysteine a modifiable risk factor for stroke? Nat Clin Pract Neurol 2006;2:26-33.
Kittner SJ, Giles WH, Macko RF, Hebel JR, Wozniak MA, Wityk RJ, Stolley PD, Stern BJ, Sloan MA, Sherwin R, Price TR, McCarter RJ, Johnson CJ, Earley CJ, Buchholz DW, Malinow MR: Homocyst(e)ine and risk of cerebral infarction in a biracial population: the stroke prevention in young women study. Stroke 1999;30:1554-1560.

88 Furie KL, Kelly PJ: Homocyst(e)ine and stroke. Semin Neurol 2006;26:24-32.

89 Wang H, Fan D, Zhang H, Fu Y, Zhang J, Shen Y: Serum level of homocysteine is correlated to carotid artery atherosclerosis in Chinese with ischemic stroke. Neurol Res 2006;28:25-30.

90 Tanriverdi $\mathrm{H}$, Evrengul H, Tanriverdi S, Kuru O, Seleci D, Enli Y, Kaftan A, Kilic M: Carotid intima-media thickness in coronary slow flow: relationship with plasma homocysteine levels. Coron Artery Dis 2006;17: 331-337.

91 Clarke R, Lewington S: Homocysteine and coronary heart disease. Semin Vasc Med 2002;2:391-399.

92 Troughton JA, Woodside JV, Young IS, Arveiler D, Amouyel P, Ferrieres J, Ducimetiere P, Patterson CC, Kee F, Yarnell JW, Evans A; PRIME Study Group: Homocysteine and coronary heart disease in the PRIME study. Atherosclerosis 2007;191:90-97.

93 Aronow WS: Homocysteine: the association with atherosclerotic vascular disease in older persons. Geriatrics 2003;58:27-28.

94 Rice TW, Lumsden AB: Optimal medical management of peripheral arterial disease. Vasc Endovascular Surg 2006;40:312-327.

95 Haim M, Tanne D, Goldbourt U, Doolman R, Boyko V, Brunner D, Sela BA, Behar S: Serum homocysteine and long-term risk of myocardial infarction and sudden death in patients with coronary heart disease. Cardiology 2007;107:52-56.

96 Salahuddin MI, Ahmed SI: Homocysteine level in patients with established transmural myocardial infarction. J Coll Physicians Surg Pak 2005;15:520-523.

97 Kaul S, Zadeh AA, Shah PK: Homocysteine hypothesis for atherothrombotic cardiovascular disease: not validated. J Am Coll Cardiol 2006;48:914-923.

98 Mohan IV, Jagroop IA, Mikhailidis DP, Stansby G: Homocysteine activates platelets in vitro. Clin Appl Thromb Hemost, in press.

99 Minuz P, Patrignani P, Gaino S, Degan M, Menapace L, Tommasoli R, Seta F, Capone ML, Tacconelli S, Palatresi S, Bencini C, Del Vecchio C, Mansueto G, Arosio E, Santonastaso CL, Lechi A, Morganti A, Patrono C: Increased oxidative stress and platelet activation in patients with hypertension and renovascular disease. Circulation 2002;106: 2800-2805. 
100 Olivieri O, Friso S, Trabetti E, Girelli D, Pizzolo F, Faccini G, Stranieri C, Pignatti PF, Corrocher R: Homocysteine and atheromatous renal artery stenosis. Clin Exp Med 2001;1:211-218.

101 Athyros VG, Mikhailidis DP, Papageorgiou AA, Symeonidis AN, Pehlivanidis AN, Bouloukos VI, Elisaf M: The effect of statins versus untreated dyslipidemia on renal function in patients with coronary heart disease: a subgroup analysis of the Greek atorvastatin coronary heart disease evaluation (GREACE) study. J Clin Pathol 2004; 57:728-734.

102 Athyros VG, Elisaf M, Papageorgiou AA, Symeonidis AN, Pehlivanidis AN, Bouloukos VI, Milionis HJ, Mikhailidis DP; GREACE Study Collaborative Group: Effect of statins versus untreated dyslipidemia on serum uric acid levels in patients with coronary heart disease: a subgroup analysis of the GREek Atorvastatin Coronary-heart-disease Evaluation (GREACE) study. Am J Kidney Dis 2004;43:589-599.

103 Elisaf M, Mikhailidis DP: Statins and renal function. Angiology 2002;53:493-502.

-104 Segura J, Ruilope LM: Minor abnormalities of renal function: a situation requiring integrated management of cardiovascular risk. Fundam Clin Pharmacol 2005; 19: 429-437.

105 Jose P, Skali H, Anavekar N, Tomson C, Krumholz HM, Rouleau JL, Moye L, Pfeffer MA, Solomon SD: Increase in creatinine and cardiovascular risk in patients with systolic dysfunction after myocardial infarction. J Am Soc Nephrol 2006;17:28862891.

106 Jaffe AS, Krumholz HM, Catellier DJ, Freedland KE, Bittner V, Blumenthal JA, Calvin JE, Norman J, Sequeira R, O’Connor C, Rich MW, Sheps D, Wu D; Enhancing Recovery in Coronary Heart Disease Patients (ENRICHD) Trial Investigators: Prediction of medical morbidity and mortality after acute myocardial infarction in patients at increased psychosocial risk in the Enhancing Recovery in Coronary Heart Disease Patients (ENRICHD) study. Am Heart J 2006;152:126-135.

107 Williams BA, Wright RS, Murphy JG, Brilakis ES, Reeder GS, Jaffe AS: A new simplified immediate prognostic risk score for patients with acute myocardial infarction. Emerg Med J 2006;23:186-192.

108 Bertomeu-Gonzalez V, Nunez J, Nunez E, Facila L, Sanchis J, Bodi V, Pellicer M, Bosch MJ, Martinez A, Chorro FJ, Llacer A: Prognostic effect of renal dysfunction after ST-segment elevation myocardial infarction with and without heart failure. Int J Cardiol 2006;112:159-165.
Anavekar NS, McMurray JJ, Velazquez EJ, Solomon SD, Kober L, Rouleau JL, White HD, Nordlander R, Maggioni A, Dickstein $\mathrm{K}$, Zelenkofske S, Leimberger JD, Califf RM, Pfeffer MA: Relation between renal dysfunction and cardiovascular outcomes after myocardial infarction. N Engl J Med 2004;351:1285-1295.

110 Koren-Morag N, Goldbourt U, Tanne D: Renal dysfunction and risk of ischemic stroke or TIA in patients with cardiovascular disease. Neurology 2006;67:224-228.

111 Irie F, Iso H, Sairenchi T, Fukasawa N, Yamagishi K, Ikehara S, Kanashiki M, Saito Y, Ota H, Nose T: The relationships of proteinuria, serum creatinine, glomerular filtration rate with cardiovascular disease mortality in Japanese general population. Kidney Int 2006;69:1264-1271.

112 Hillege HL, Nitsch D, Pfeffer MA, Swedberg K, McMurray JJ, Yusuf S, Granger CB, Michelson EL, Ostergren J, Cornel JH, de Zeeuw D, Pocock S, van Veldhuisen DJ; Candesartan in Heart Failure: Assessment of Reduction in Mortality and Morbidity (CHARM) Investigators: Renal function as a predictor of outcome in a broad spectrum of patients with heart failure. Circulation 2006;113:671-678.

113 Zhang Y, Ge JB, Qian JY, Ye ZB: Prevalence and risk factors of atherosclerotic renal artery stenosis in 1200 Chinese patients undergoing coronary angiography. Nephron Clin Pract 2006;104:c185-c192.

114 Saleh AA, Bustami BB: Prevalence of renal artery stenosis in patients undergoing routine cardiac catheterization. Saudi Med J 2004;25:52-54.

115 Rigatelli G, Rigatelli G: Vascular profile of patients with multivessel coronary artery disease. Int J Cardiol 2006;106:35-40.

116 Edwards MS, Craven TE, Burke GL, Dean $\mathrm{RH}$, Hansen KJ: Renovascular disease and the risk of adverse coronary events in the elderly: a prospective, population-based study. Arch Intern Med 2005;165:207-213.

117 Buller CE, Nogareda JG, Ramanathan K, Ricci DR, Djurdjev O, Tinckam KJ, Penn IM, Fox RS, Stevens LA, Duncan JA, Levin A: The profile of cardiac patients with renal artery stenosis. J Am Coll Cardiol 2004;43: 1606-1613.

118 Lanzer P: Vascular multimorbidity in patients with a documented coronary artery disease. Z Kardiol 2003;92:650-659.

119 Losito A, Errico R, Santirosi P, Lupattelli T, Scalera GB, Lupattelli L: Long-term followup of atherosclerotic renovascular disease: beneficial effect of ACE inhibition. Nephrol Dial Transplant 2005;20:1604-1609.

120 Cheung CM, Wright JR, Shurrab AE, Mamtora H, Foley RN, O’Donoghue DJ, Waldek S, Kalra PA: Epidemiology of renal dysfunction and patient outcome in atherosclerotic renal artery occlusion. J Am Soc Nephrol 2002;13:149-157.
121 Chabova V, Schirger A, Stanson AW, McKusick MA, Textor SC: Outcomes of atherosclerotic renal artery stenosis managed without revascularization. Mayo Clin Proc 2000;75:437-444.

122 Tanemoto M, Saitoh H, Satoh F, Satoh H, Abe T, Ito S: Predictors of undiagnosed renal artery stenosis among Japanese patients with risk factors of atherosclerosis. Hypertens Res 2005;28:237-242.

123 Farmer CK, Cook GJ, Blake GM, Reidy J, Scoble JE: Individual kidney function in atherosclerotic nephropathy is not related to the presence of renal artery stenosis. Nephrol Dial Transplant 1999;14:28802884.

124 Krijnen P, van Jaarsveld BC, Deinum J, Steyerberg EW, Habbema JD: Which patients with hypertension and atherosclerotic renal artery stenosis benefit from immediate intervention? J Hum Hypertens 2004; 18:91-96.

125 Zeller T, Frank U, Muller C, Burgelin K, Sinn L, Bestehorn HP, Cook-Bruns N, Neumann FJ: Predictors of improved renal function after percutaneous stent-supported angioplasty of severe atherosclerotic ostial renal artery stenosis. Circulation 2003; 108:2244-2249.

126 Roussos L, Christensson A, Thompson O: A study on the outcome of percutaneous transluminal renal angioplasty in patients with renal failure. Nephron Clin Pract 2006;104:c132-c142.

127 Mistry S, Ives N, Harding J, Fitzpatrick-Ellis K, Lipkin G, Kalra PA, Moss J, Wheatley $\mathrm{K}$ : Angioplasty and STent for Renal Artery Lesions (ASTRAL trial): rationale, methods and results so far. J Hum Hypertens 2007;21:511-515.

128 Cooper CJ, Murphy TP, Matsumoto A, Steffes M, Cohen DJ, Jaff M, Kuntz R, Jamerson K, Reid D, Rosenfield K, Rundback J, D’Agostino R, Henrich W, Dworkin L: Stent revascularization for the prevention of cardiovascular and renal events among patients with renal artery stenosis and systolic hypertension: rationale and design of the CORAL trial. Am Heart J 2006;152:59-66.

129 Ganotakis ES, Papadakis JA, Vrentzos GE, Mikhailidis DP: The effects of antihypertensive therapy on haemostatic parameters. Curr Pharm Des 2003;9:2445-2464.

130 Tsimihodimos V, Kostoula A, Kakafika A, Bairaktari E, Tselepis AD, Mikhailidis DP, Elisaf M: Effect of fenofibrate on serum inflammatory markers in patients with high triglyceride values. J Cardiovasc Pharmacol Ther 2004;9:27-33.

131 Rizos E, Kostoula A, Elisaf M, Mikhailidis DP: Effect of ciprofibrate on C-reactive protein and fibrinogen levels. Angiology 2002; 53:273-277. 
132 Ridker PM, Cannon CP, Morrow D, Rifai $\mathrm{N}$, Rose LM, McCabe CH, Pfeffer MA, Braunwald E; Pravastatin or Atorvastatin Evaluation and Infection Therapy-Thrombolysis in Myocardial Infarction 22 (PROVE IT-TIMI 22) Investigators: C-reactive protein levels and outcomes after statin therapy. N Engl J Med 2005;352:20-28.

133 Tsimikas S, Willerson JT, Ridker PM: C-reactive protein and other emerging blood biomarkers to optimize risk stratification of vulnerable patients. J Am Coll Cardiol 2006;47:C19-C31.

134 Prasad K: C-reactive protein (CRP)-lowering agents. Cardiovasc Drug Rev 2006;24 33-50.

135 Curran MP, Wagstaff AJ: Spotlight on estradiol and norgestimate as hormone replacement therapy in postmenopausal women. Treat Endocrinol 2002;1:127-129.

136 Keller C: Apheresis in coronary heart disease with elevated $\mathrm{Lp}$ (a): a review of $\mathrm{Lp}$ (a) as a risk factor and its management. Ther Apher Dial 2007;11:2-8.

137 Herrmann W, Herrmann M, Obeid R: Hyperhomocysteinaemia: a critical review of old and new aspects. Curr Drug Metab 2007;8:17-31.

138 Collins R, Armitage J, Parish S, Sleigh P, Peto R; Heart Protection Study Collaborative Group: MRC/BHF Heart Protection Study of cholesterol-lowering with simvastatin in 5963 people with diabetes: a randomised placebo-controlled trial. Lancet 2003;361:2005-2015.

139 Griffin KA, Bidani AK: Progression of renal disease: renoprotective specificity of renin-angiotensin system blockade. Clin J Am Soc Nephrol 2006;1:1054-1065.
140 De Silva R, Loh H, Rigby AS, Nikitin NP, Witte KK, Goode K, Bhandari S, Nicholson A, Clark AL, Cleland JG: Epidemiology, associated factors, and prognostic outcomes of renal artery stenosis in chronic heart failure associated with magnetic resonance angiography. Am J Cardiol 2007;100:273279.

141 Levin A, Linas S, Luft FC, Chapman AB, Textor S; ASN HTN Advisory Group: Controversies in renal artery stenosis: a review by the American Society of Nephrology Advisory Group on Hypertension. Am J Nephrol 2007;27:212-220.

142 Ahmed A, Nampoory MR, Sheikh M, Johny $\mathrm{KV}$ : Renal artery stenosis in patients with peripheral vascular disease in Kuwait. Med Princ Pract 2005;14:386-389.

143 Pillay WR, Kan YM, Crinnion JN, Wolfe JH; Joint Vascular Research Group, UK: Prospective multicentre study of the natural history of atherosclerotic renal artery stenosis in patients with peripheral vascular disease. Br J Surg 2002;89:737-740.

144 Zierler RE, Bergelin RO, Isaacson JA, Strandness DE Jr: Natural history of atherosclerotic renal artery stenosis: a prospective study with duplex ultrasonography. J Vasc Surg 1994;19:250-257.

145 Zierler RE, Bergelin RO, Polissar NL, Beach KW, Caps MT, Cantwell-Gab K, Davidson RC, Strandness DE Jr: Carotid and lower extremity arterial disease in patients with renal artery atherosclerosis. Arch Intern Med 1998;158:761-767.

146 Olin JW, Melia M, Young JR, Graor RA, Risius B: Prevalence of atherosclerotic renal artery stenosis in patients with atherosclerosis elsewhere. Am J Med 1990;88:46N$51 \mathrm{~N}$.
47 Kulbaski MJ, Kosinski AS, Smith RB 3rd, Salam AA, Dodson TF, Lumsden AB, Chaikof EL: Concomitant aortic and renal reconstruction in patients on an intensive antihypertensive medical regimen: long-term outcome. Ann Vasc Surg 1998;12:270-277.

148 Cambria RP, Brewster DC, L'Italien G, Koustas G, Atamian S, LaMuraglia GM, Gertler JP, Abbott WM: Simultaneous aortic and renal reconstruction: evolution of an eighteen-year experience. J Vasc Surg 1995;21:916-924.

149 McNeil JW, String ST, Pfeiffer RB Jr: Concomitant renal endarterectomy and aortic reconstruction. J Vasc Surg 1994;20:331336.

150 Kuroda S, Nishida N, Uzu T, Takeji M, Nishimura M, Fujii T, Nakamura S, Inegata T, Yutani C, Kimura G: Prevalence of renal artery stenosis in autopsy patients with stroke. Stroke 2000;31:61-65.

151 Uzu T, Takeji M, Yamada N, Fujii T, Yamauchi A, Takishita S, Kimura G: Prevalence and outcome of renal artery stenosis in atherosclerotic patients with renal dysfunction. Hypertens Res 2002;25:537-542.

152 Edwards MS, Hansen KJ, Craven TE, Bleyer AJ, Burke GL, Levy PJ, Dean RH: Associations between renovascular disease and prevalent cardiovascular disease in the elderly: a population-based study. Vasc Endovascular Surg 2004;38:25-35.

153 Zoccali C, Mallamaci F, Finocchiaro P: Atherosclerotic renal artery stenosis: epidemiology, cardiovascular outcomes, and clinical prediction rules. J Am Soc Nephrol 2002;13:S79-S83. 